
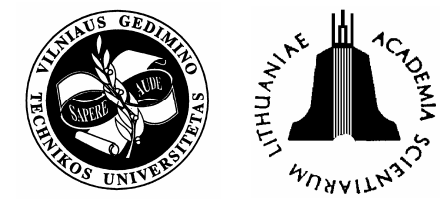

http:/www.jcem.vgtu.lt

2007, Vol XIII, No 1, 11-17

\title{
STRUCTURAL DESIGN OF POLYMER PROTECTIVE COATINGS FOR REINFORCED CONCRETE STRUCTURES. PART I: THEORETICAL CONSIDERATIONS
}

\author{
Zenonas Kamaitis \\ Dept of Bridges and Special Structures, Vilnius Gediminas Technical University, \\ Sauletekio al.11,LT-10223 Vilnius, Lithuania.E-mail: zenonas.kamaitis@ts.vtu.lt \\ Received 20 Feb 2006; accepted 18 May 2006
}

\begin{abstract}
In a number of situations reinforced concrete structures must be protected by barrier materials to prevent contact with aggressive agents. One of the ways to protect concrete structures from corrosion is to use protective polymer coatings. Polymers as coating materials are not totally resistant and impermeable to all aggressive agents. Gases, vapors and liquids penetrate into a polymer so that the polymer mass swells and eventually disintegrates. However, the penetration/disintegration progresses at a much lower rate than that in the concrete. Surface coatings are able to reduce considerably the penetration, to slow down the rate of deterioration of concrete cover and to overcome most durability problems associated with external attack. In this article the mechanism of degradation of polymer coatings are analyzed. Methodology and predictive models for the degradation over time caused by aggressive actions of polymer coatings are presented. Proposed models can be applied to design of polymer coatings. Such a design of coatings is presented in a simple form for engineering design purposes.
\end{abstract}

Keywords: reinforced concrete, corrosion, polymer coatings, physical/chemical resistance, diffusion, adhesion, design.

\section{Introduction}

Corrosion is a serious problem for the durability of reinforced concrete (RC) structures. One of the ways to protect RC structures from corrosion is to use protective coatings. There may be need for protection and prevention of chemical attack on concrete in such places as industrial floors, chemical process plants, tanks, silos, industrial chimneys, sewers and sewage plants. In special circumstances protection might be necessary in such ordinary locations as foundations, bridge structures, or dams. The barrier coatings of non-degradable materials are to insulate the concrete and steel reinforcement from the surrounding environment and to increase durability of a new structure or extend the service life of an existing one.

A large number and variety of protective surface treatments and coatings on the base of polymers have been developed for concrete surfaces in those instances when a special protection against aggressive attack is necessary. Polymer compositions are the multi component systems and relatively expensive materials. To optimize properties and costs, coatings have to be carefully formulated, placed and cured. Minor variations in formulation can lead to very substantial changes in performance. Performance or the effectiveness of any barrier coating in any exposure is a complex function of material type and formulation, coating thickness, surface preparation, and adhesion between coatings and substrate. Coatings have to be formulated to be compatible with the exposure conditions.
Methods for improving the performance of concrete structures by coatings have been investigated for many years [1-17] and many standards are published (ASTM, ACI, JIS, JASS etc) [18]. Little knowledge is available for the efficiency of the various protective measures for concrete and further research on their technical and economical effectiveness is needed.

Guide specifications from the manufacturers suggests what kinds of protection have been used against specific exposure without indicating how this exposure will effect the performance of a barrier coating in a given situation avec prolonged period of time. Protective polymer barriers generally have a limited service life. A serious problem for a structural engineer is in selecting an appropriate polymer material and its formulation for a particular situation and to assess the factors affecting a coating performance over the life of a structure. For this reason it is desirable that theoretical methods should exist. Unfortunately, the theoretical methods of design of protective coatings for RC have up until now achieved only a very limited success [eg 3, 5, 12, 14, 15]. One reason is that deteriorating agents can have quite different effects on different polymer materials leading sometimes to large scatter in the experimental data and high level of uncertainty.

In this article the mechanisms of degradation of polymer coatings are analysed. Deterioration models of polymer coatings are presented. The proposed models can be applied to the design of polymer coatings. Such a design of coatings is presented in a simple form for engineering design purposes. 


\section{Mechanism of polymer coatings degradation}

It should be noted that polymer materials are not totally resistant and impermeable to all aggressive agents and do not provide a total protection. Chemical/physical degradation of polymers and rebounding of coatings are the major phenomena affecting the durability of anticorrosion protection. The mechanisms of destructive processes in such heterogeneous materials as polymer composites are complicated and not completely understood. Degradation of polymers mainly involves swelling, dissolution and scission of molecular chain bonds. A wide variety of reactions is possible for polymer degradation. The transport of gases and liquids aggressive to substrate into or through polymer coating is the major problem of its delamination.

Various mechanisms of deterioration of polymer composites and coatings are summarised in Table 1 [3].

There are many parameters that influence the deterioration process of coatings, such as chemical agents, temperature, solar radiation, pressure, abrasion, cyclic temperature-moisture changes etc. All these parameters can occur simultaneously or they can be complementary to one another. The barrier may be subjected to continuous exposure or intermittent contact occasioned by splash, spray, or accidental wetting with aggressive substances. Usually chemical/physical degradation and rebounding of coatings is the major problem of degradation leading to their cracking and delamination.

On the basis of the degradation processes the basic requirements for protective coatings of concrete structures in aggressive environments can be formulated. They are as follows:

- resistivity to chemical/physical actions;

- low permeability to water, solutions and gases;

- good bond to concrete and/or steel;

- sufficient flexibility to avoid cracking caused by thermal or mechanical stresses;

- similar physical properties of the overlay material and underlying concrete;
- adequate abrasion or skid resistance;

- resistivity to chemical action of concrete and humidity in concrete;

- bridging of fine cracks in concrete.

\section{Modelling of polymer coatings degradation}

As is shown in Table 1, the degradation of coatings is a complex interaction of physical and chemical processes. The damaging process in polymer coatings is governed mainly by permeability/diffusion and chemical/ physical degradation due to losses in intermolecular cohesion and interaggregate adhesion. Thus, the changes in the material properties, $R$, are due to diffusion and chemical reactions:

$$
\frac{d R}{d t}=\alpha_{1} \frac{d c}{d t}+\alpha_{2} \frac{d r}{d t}
$$

where the first term represents the rate of diffusion and the second one is the rate of chemical reactions; $\alpha_{1}$ and $\alpha_{2}$ are constant parameters.

It is recognised that diffusion is the principal mechanism that can be described by the well-known Fick's second law taking into consideration the chemical reaction:

$$
\frac{d c_{x}}{d t}=D \frac{d^{2} c_{x}}{d x^{2}}-k\left(c_{x}-c_{r}\right),
$$

$$
\text { with } \begin{aligned}
c & =c_{0} \text { at } t \geq 0 \text { and } x=0 ; \\
c & =c_{x} \text { at } t>0 \text { and } d_{p c} \geq x>0 ; \\
c & =0 \text { at } t=0 \text { and } d_{p c} \geq x>0 ; \\
c_{x} & >c_{r} \text { at } d_{p c} \geq x>0 ; \\
c & \leq c_{0} \text { at } t>0 \text { and } d_{p c} \geq x>0
\end{aligned}
$$

\begin{tabular}{|c|c|c|c|}
\hline $\begin{array}{l}\text { Type of } \\
\text { action }\end{array}$ & Nature of action & Conditions and types of destructive processes & $\begin{array}{l}\text { Type of deterioration } \\
\text { of coating }\end{array}$ \\
\hline I & $\begin{array}{l}\text { External physical or chemical (water, } \\
\text { solvents) }\end{array}$ & $\begin{array}{l}\text { Absorption and diffusion, saponification at the } \\
\text { interface coating-substrate, dissolution of polymer }\end{array}$ & $\begin{array}{l}\text { Dissolution and de- } \\
\text { lamination }\end{array}$ \\
\hline II & External chemical & Absorption and diffusion, chemical destruction & Degradation, cracking \\
\hline III & External physical (temperature, radiation) & $\begin{array}{l}\text { Activation of ageing, thermal and ultraviolet de- } \\
\text { struction }\end{array}$ & Degradation, cracking \\
\hline IV & $\begin{array}{l}\text { External mechanical (stresses, abrasion, } \\
\text { impact) }\end{array}$ & Mechanical stresses & $\begin{array}{l}\text { wear, cracking, } \\
\text { punching }\end{array}$ \\
\hline $\mathrm{V}$ & $\begin{array}{l}\text { Internal physical (temperature) and } \\
\text { chemical (shrinkage) }\end{array}$ & Internal stresses & Cracking, rebounding \\
\hline VI & $\begin{array}{l}\text { Internal mechanical (pressure of liquids } \\
\text { and vapour, freezing of water) }\end{array}$ & $\begin{array}{l}\text { Pores and cracks in substrate, capillary and osmotic } \\
\text { pressure }\end{array}$ & $\begin{array}{l}\text { Blistering, bubbling } \\
\text { and peeling }\end{array}$ \\
\hline
\end{tabular}

where $c$ is the concentration of aggressive agents; $D$ is diffusion coefficient; $k$ - the rate of chemical reaction; $c_{r}$ - the steady state concentration of fluid; $d_{p c}-$ the thickness of polymer coating.

In the case of stationary diffusion process $\frac{d c_{x}}{d t}=0$

Table 1. Classification of degradation of polymer coatings 
and

$$
D \frac{d^{2} c_{x}}{d x^{2}}=k\left(c_{x}-c_{r}\right)
$$

Solution of Eq (3) may take the following form [15]:

$$
\frac{c_{x}-c_{r}}{c_{0}-c_{r}}=\exp \left(-x \sqrt{\frac{k}{D}}\right)
$$

from which the penetration depth of the aggressive agent can be obtained:

$$
x \cong \sqrt{\frac{D}{k}} \ln \frac{c_{x}-c_{r}}{c_{0}-c_{r}} .
$$

The physical model of liquid penetrating through a coating and its surface degradation is shown in Fig 1.

a)

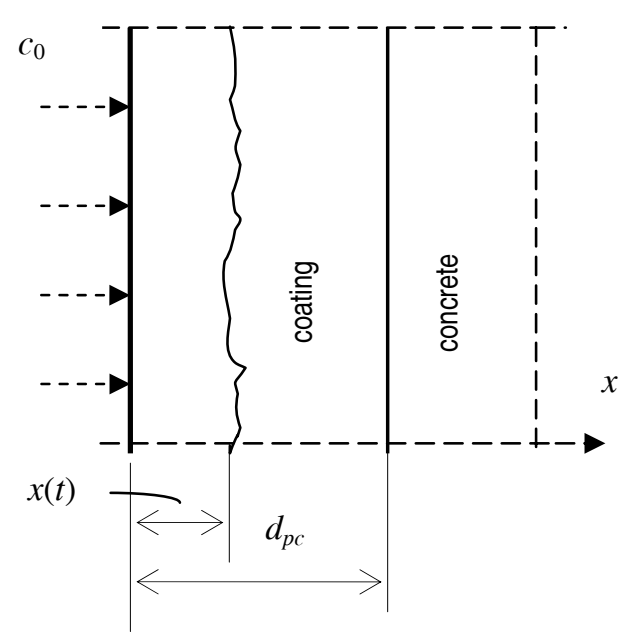

b)

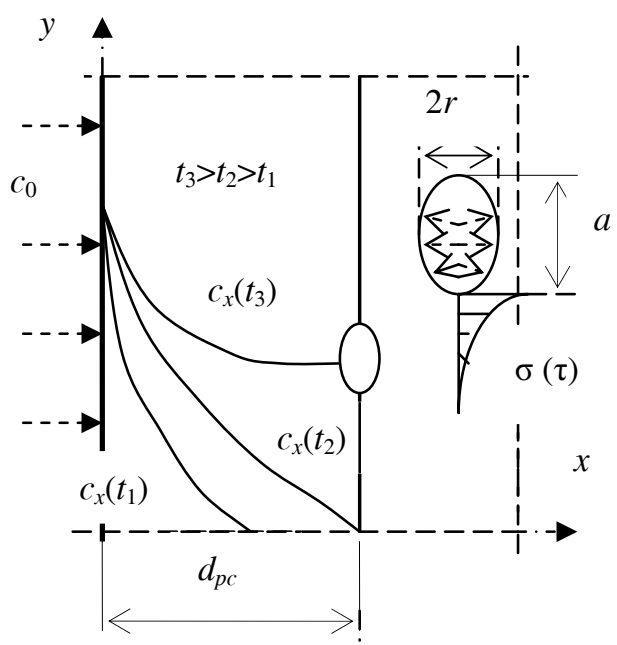

Fig 1. Surface degradation of coating (a) and concentration profiles for diffusion taken at different time (b)

Penetration of fluids into the coating is accompanied by chemical reactions with polymer molecules and fillers/aggregates (if present). Two different phenomena can proceed at the same or at different rates. When the rate of penetration exceeds the rate of chemical reactions, the aggressive substance penetrates into the barrier, reacts with barrier material resulting in disintegration of barrier.
Due to chemical reactions the concentration of aggressive agents in solution decreases. If chemical reactions prevail over diffusions, degradation of coating begins from surface leading to a decrease of coating thickness. In both cases the damaging process can be viewed as a pure diffusion or a degradation of the mechanical or geometrical (eg, coating thickness) properties.

An apparent pure diffusion process based on Fick's second law can be represented by the following equation:

$$
c(x ; t)=\left(1-\operatorname{erf} \frac{x}{2 \sqrt{D t}}\right),
$$

where $c(x ; t)$ and $c_{0}$ are concentrations of aggressive agents at depth $x$ after time $t$ and on surface, respectively; $D$ is an apparent diffusion coefficient of coating; erf is the standard error function.

The model may be rewritten for design purposes as follows:

$$
x(t)=\sqrt{\pi D t}\left(1-\frac{c_{x}}{c_{0}}\right)
$$

or

$$
t=\frac{x^{2}(t)}{\pi D\left(1-\frac{c_{x}}{c_{0}}\right)^{2}} .
$$

When $c_{x}$ is a set equal to the aggressiveness threshold level $c_{c r i t}, \mathrm{Eq}(7)$ is solved for $x=d_{p c}$. When $x(t)=d_{p c}$ and $c_{x}=c_{c r i t}, \mathrm{Eq}(8)$ is solved for $t=t_{p c}$, where $t_{p c}$ is the coating service life.

Degradation of polymer coating and decreasing its protection ability with time due to chemical/physical reactions can be expressed as

$$
R(t)=R_{0} \varphi_{R}(t)
$$

where $R_{0}$ - the initial resistance and $\varphi_{R}(t)$ - resistance degradation function.

The values of $c_{x}, c_{0}, D, t, x\left(d_{p c}\right), R(t), R_{0}, \varphi_{R}(t)$ are random variables, each with their own statistical distributions, means and variances.

When the substance penetrates the coating and reaches the surface of concrete, the following two possible deterioration mechanisms should be considered:

- diffusion of agents into concrete with increasing its concentration on the concrete surface, when the agent is not aggressive to concrete;

- destruction of adhesion between coating and substrate, then rebounding and cracking of coating, when the substance reacts with concrete.

\section{Rebounding and cracking of coatings}

Three main causes can lead to rebounding of coatings:

- shrinkage of polymer composition during formation of coating;

- thermal deformations during operation in service;

- penetration of aggressive agents through coating and destruction of the adhesion between coating and substrate.

Polymer coatings have to resist cracking and rebounding due to curing contraction stresses and thermal 
stresses under service conditions. Applied to the concrete substrate due to adhesion between coating and substrate, the polymer coating is restrained to free deformations and internal stresses inevitable appear. The type and magnitude of these stresses will depend on the type of polymer composition, temperature of the environment, the geometry of the protected structure, the restraint degree. Two types of stresses should be considered: normal (tension) stresses in the coating and shear stresses in the interface between coating and substrate.

Let's consider the variation of coating force along the coating. The forces acting on two sections of the coating, distance $d x$ apart, are shown in Fig 2. The coating/substrate interface equilibrium is given by:

$$
d F+\tau b d x=0
$$

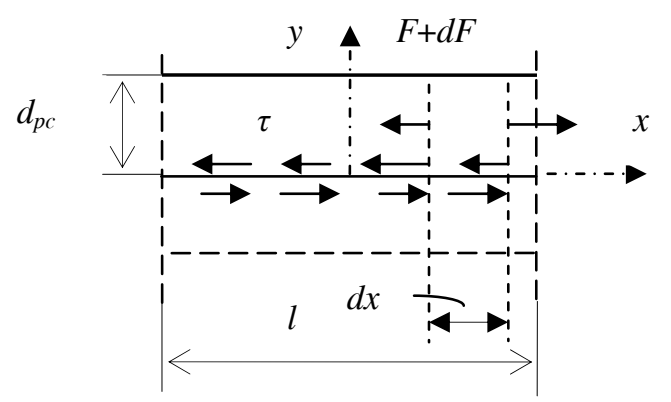

Fig 2. Stresses on elementary strip $d x$ of coating due to external or/and internal actions

If the coating layer at time $t$ is assumed to be linearly elastic, with Young's modulus $E_{p c}(t)$ and shear modulus $G_{p c}(t)$, and to have width $b=1$ and thickness $d_{p c}$, the differential equation of equilibrium can be obtained:

$$
\frac{d^{2} u_{x}}{d x^{2}}-n^{2} u_{x}=-n^{2} \varepsilon x,
$$

where $n^{2}=\frac{G_{p c}(t)}{d_{p c} E_{p c}(t)}$.

Solving Eq (11) with boundary conditions $u_{x}=0$ at $x=0$ and $F=0$ at $x=l / 2$, we obtain the normal and shear stresses in the format of hyperbolic functions [3]:

$$
\begin{gathered}
\sigma=\varepsilon E(t)\left[1-\frac{\operatorname{chn} x}{\operatorname{ch} 0,5 l}\right] ; \\
\tau=\varepsilon G(t) \frac{\operatorname{shn} x}{n \operatorname{ch} 0,5 n l} .
\end{gathered}
$$

At $x=0$

$$
\sigma_{\max }=\varepsilon E_{p c}(t)\left(1-\frac{1}{c h 0,5 n l}\right)
$$

at $x=0,5 l$

$$
\begin{gathered}
\tau_{\max }=\varepsilon\left[d_{p c} E_{p c}(t) G_{p c}(t)\right]^{1 / 2} t h 0,5 n l ; \\
\varepsilon_{\max }=\varepsilon\left(1-\frac{1}{c h 0,5 n l}\right) .
\end{gathered}
$$

Stress distribution in coating is shown in Fig 3.

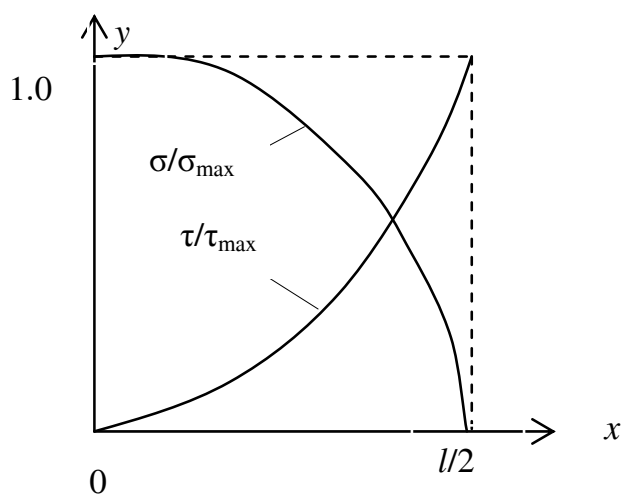

Fig 3. Distribution of traction and shear stresses along the coating

The protective barrier would crack when the residual tensile stress, $\sigma_{\max }$, exceeds its tensile strength. Failure of the coating occurs by delamination if $\tau_{\max }>\tau_{c o n}$. In general, the bond strength is limited by shear strength of concrete substrate $\left(\tau_{c o n}\right)$. However, some of the stress is relaxed. Cracking and rebounding often occur with some formulations of epoxy and polyester coatings, especially with thick coatings or large protected areas.

If $\varepsilon_{\text {max }}=\varepsilon_{t u}$ from Eq (16) crack spacing:

$$
l_{c r}=2\left[\frac{d_{p c} E_{p c}(t)}{G_{p c}(t)}\right]^{1 / 2} \operatorname{arch} \frac{\varepsilon}{\varepsilon-\varepsilon_{t u}} .
$$

It follows from this formula that if $\varepsilon \leq \varepsilon_{t u}, l_{c r}=\infty$, no cracking is expected.

Similar approach is presented in [14].

As mentioned above, the normal and shear peak stresses will decrease with time as a result of relaxation. The change in stresses with time, for example, can be expressed by using a Maxwell rheological model:

for traction $\quad \frac{d \sigma}{d t}=E \frac{d \varepsilon}{d t}-\frac{\sigma}{t_{r e l}}$,

for shear

$$
\frac{d \tau}{d t}=G \frac{d \gamma}{d t}-\frac{\tau}{t_{r e l}}
$$

where $\varepsilon$ and $\gamma$ are tension and shear deformations; $t_{r e l}$ is relaxation time.

In case of a constant deformation $(\varepsilon=$ const and $\gamma=$ const $) \frac{d \varepsilon}{d t}=0$ and $\frac{d \gamma}{d t}=0$ and then we obtain

$$
\frac{d \sigma}{d t}=-\frac{\sigma}{t_{r e l}}
$$

and

$$
\frac{d \tau}{d t}=-\frac{\tau}{t_{r e l}}
$$

The integration of Eqs (20) and (21) gives the following general expressions:

$$
\sigma(t)=\sigma_{0} \exp \left(-\frac{t}{t_{\text {rel }}}\right)=\sigma_{0} K_{t . r e l}
$$




$$
\tau(t)=\tau_{0} \exp \left(-\frac{t}{t_{\text {rel }}}\right)=\tau_{0} K_{t . r e l}
$$

where $\sigma_{0}$ and $\tau_{0}$ are initial stresses at $t=0 ; K_{t . r e l}$ is coefficient of relaxation.

Rebounding of coatings due to diffusion process typically involves 3 phases: penetration and migration of deleterious substances through coating $\left(t_{c}\right)$, destruction of adhesion between coating and substrate $\left(t_{a d h}\right)$, and delamination followed by cracking of coating $\left(t_{c r}\right)$ until an unacceptable level of coating loss occurred. Thus, the durability of coating can be expressed as follows:

$$
t_{p c}=t_{c}+t_{a d h}+t_{c r} .
$$

If the agents get to the coating-concrete interface, the bond becomes thermodynamically unstable and concentration of stresses occurs. This leads to the formation of a crack that then rapidly propagates. Debounding occurs, followed by delamination. Causes of stress concentration may include small pores and micro-cracks that always exist at the surface of concrete. The classical equation for calculating the magnitude of stress concentration at a defect of the type shown in Fig 1, b is

$$
\sigma_{c}=\sigma_{0}\left[1+2\left(\frac{a}{r}\right)^{1 / 2}\right]=\sigma_{0} k_{t},
$$

where $\sigma_{c}$ is the local stress (maximum stress at the crack tip), $\sigma_{0}-$ the nominal applied tensile stress; $2 a$ - the defect size, $r$ - the radius of the defect, and $k_{t}-$ stress concentration factor. For a sphere where $a=r, k_{t}=3$. For $a \rightarrow \infty, k_{t} \rightarrow \infty$. Obviously, this does not occur in practice.

The stress in the vicinity of defect (crack) can be defined using the well-known critical stress intensity factor, $K_{I c}$, as [16]

$$
\sigma_{c}=\frac{K_{I c}}{Y \sqrt{\pi a}} .
$$

Here $Y$ is a dimensionless parameter that depends on the crack and specimen geometries. Mathematical expressions for $Y$ are often relatively complex. For a coating as the plate of an infinite width for the first approximation could be taken as $Y \cong 1$. Critical stress intensity factor, $K_{I c}$, for concrete is $0,2-0,4 \mathrm{MN} / \mathrm{m}^{3 / 2}$, for hardened epoxy is $0,3-0,5 \mathrm{MN} / \mathrm{m}^{3 / 2}$, for rubber- modified epoxy is $2,2 \mathrm{MN} / \mathrm{m}^{3 / 2}[16]$.

Delamination of coating can occur when stress intensity factor, $K_{I}$, is above $K_{I c}$ and above $K_{\text {Icor }}$, eg, $K_{\text {Icor }}<$ $K_{I}>K_{I c}$, where $K_{I c o r}$ is critical stress intensity factor after a long exposure under stress to aggressive environments. This failure arises because cracks at interface are able to grow to the critical dimensions due to corrosion characteristics of the environment penetrated to the interface coating-substrate. It should be stressed that local defects in the substrate or in coating may lead to local stress concentrations resulting in premature failure of coating. The values of $K_{\text {Icor }}$ have to be determined experimentally.

\section{Principles of protective coatings design}

The design of an appropriate protective system for new or existing structures is a complex process involving:
- identification of service environment of the particular structure in the original design;

- identification and assessment of the condition state and deterioration (if any) of the existing structure;

- selection of the appropriate protection system;

- definition of coating parameters: type of binder, formulation, cover thickness;

- anticipation of time between periodic recoating.

As is stated in previous sections, the performance/efficiency of any coating depends on its chemical/physical resistance to disintegration, permeability, extensibility, mechanical resistance (eg, abrasion, punching), and adhesion to concrete or steel. In this study the mechanical stresses due to exterior loading are not considered.

Traditionally codes and recommendations contain requirements for structural design in terms of resistance load format. Similarly to that design concept, the design of coatings must be developed on the basis of deterministic or probabilistic analysis taking into account the aggressive environment as an action and coating performance as resistance. In particular, aggressive actions as well as material and geometric properties of coatings may vary substantially.

Limit state functions can be represented in resistance or lifetime format:

$$
\begin{gathered}
g(t)=R(t)-S(t)=R_{0} \varphi_{R}(t) \theta_{R}-S(t) \theta_{S} \geq 0, \\
g(t)=t \theta_{t}-t_{d} \geq 0, \text { for all } 0<t \leq t_{d},
\end{gathered}
$$

where $g(t)$ is the margin of safety with $g(t)>0$ denotes safe and $g(t) \leq 0$ denotes failure; $R_{0}$ is protective barrier capacity in the undegrated (original) state; $\varphi_{R}(t)$ - degradation function; $\theta_{\text {. }}$ - uncertainty of the calculation models and errors in data observation and recording; $t-$ the time of assessment; $t_{d}$ - the design or target service life.

Once the limit state functions have been developed, the reliability of coating can be evaluated. The reliability verification of coating in relation to a given mode of failure in a given period of time may be defined as

$$
P\{t\}=P\{g(t) \geq 0\}=P\left\{R_{0} \varphi_{R}(t) \theta_{R} \geq S(t) \theta_{S}\right\} \geq P_{t \arg },
$$

for all

$$
0<t \leq t_{d}
$$

where $P_{\text {targ }}$ is an acceptable level of structural reliability. The service life of the coating is defined when the reliability falls below an acceptable level.

Different polymers respond in a different way to the influence of aggressive environments. The timedependent monotone decreasing degradation function $\varphi_{R}(t)$ can be expressed in different forms (linear, parabolic, square root, etc) with the following boundary conditions:

at $t=t_{0}, \varphi_{R}\left(t_{0}\right)=1,0$,

at $t=t_{d}, \varphi_{R}\left(t_{d}\right)=\varphi_{\min }$.

The design of polymer coatings according to Eqs (27), (28) and (29) requires checking the performance of coating under service conditions in general using the following four conditions:

$\diamond$ the condition determining the chemical/physical resistance with $R(t)=R_{0} \varphi_{R}\left(c_{0} ; t\right)$ and $S(t)=R_{\min }$, where 
$R_{0}$ and $R_{\min }$ are initial and minimum acceptable resistance of coating, respectively; $\varphi_{R}\left(c_{0} ; t\right)$ - degradation function of coating in a given exposure $c_{0}$ after time $t$;

$\diamond$ the condition determining the penetration through the coating with $R(t)=c_{c r}$ and $S(t)=c\left(d_{p c} ; t\right)$, where $c_{c r}$ and $c\left(d_{p c} ; t\right)$ are the critical and expected concentration of aggressive substances, respectively, on the surface of the concrete;

$\diamond$ the condition determining the cracking of the coating with $R(t)=f_{p t}(t)\left[\varepsilon_{p t}(t)\right]$ and $S(t)=\sigma_{\max }\left(\varepsilon_{\max }\right)$, where $f_{p t}(t) \quad\left[\varepsilon_{p t}(t)\right]$ is tensile strength (strain) of polymer and $\sigma_{\max }\left(\varepsilon_{\max }\right)$ is maximum stress (strain) in polymer coating;

$\diamond$ the condition determining the delamination (separation) of the coating with $R(t)=\tau_{c o n}\left[K_{I c}(t)\right]$ and $S(t)=\tau_{\max }\left[K_{\text {Icor }}(t)\right]$ or $R(t)=D_{c r}$ and $S(t)=D(t)$, where $K_{I c}(t)$ and $K_{I c o r}(t)$ are critical initial and after exposure in aggressive environment stress intensity factor, respectively; $D_{c r}$ and $D(t)$ is critical and expected degree (area or \%) of delamination, respectively.

\section{Conclusions}

Concrete is a porous material having high gas, vapour and liquid permeability leading to deterioration of reinforced concrete structures. One of the ways to protect $\mathrm{RC}$ structures from corrosion is to use protective coatings. Frequently, the coating is the main option to protect the concrete structures in service. Polymers as coating materials are not totally resistant and impermeable to all aggressive agents. It is necessary to well understand the mechanism of degradation of polymer coatings to enable design of coatings with required barrier properties.

The degradation of polymers is a complex interaction of physical and chemical processes leading to breakdown of its chemical structure as well as cracking and rebounding of protective coatings. Classification of coating degradation has been developed (Table 1). Some theoretical background of these mechanisms is presented in sections 3 and 4.

The mechanisms of degradation of polymer coatings caused by aggressive actions are analysed and predictive models for the deterioration over time have been suggested. The proposed models can be applied to design of surface polymer coatings, to preserve concrete structures against deterioration. In general, four limit states should be identified and checked to insure the durability of a coating (see section 5). Design of coatings is based on deterministic or probabilistic analysis in the resistance load format [see Eqs (27), (28), (29)] taking aggressive environment as an action and coating performance as resistance. Such a design of protective coatings is presented in a simple form for engineering design purposes.

There is a large number of polymer materials and systems on the market that claim a variety of properties. Experience shows that the processes of coating deterioration and the loss of protection ability are very complicated. The physical and chemical reactions for each protective system in particular environments have to be determined experimentally.

\section{References}

1. ROBINSON, H. Evaluation of coatings as carbonation barriers. Construction Repair, No 1, 1987, p. 12-18.

2. ATTWOOD, D.; NESSIM, M. A.; GHONEIM, A.; CORMEAU, A.; CHEUNG, M. S. Application of reliability theory to in-service monitoring and maintenance of parking garages. Canadian Journal of Civil Engineering, 18 (5), 1991, p. 781-788.

3. KAMAITIS, Z. Repair and strengthening of structures and buildings with synthetic resins. Vilnius: Technika, 1992. 280 p. (in Russian).

4. SCHIESSL, P. Draft recommendation for repair strategies for concrete structures damaged by reinforcement corrosion. RILEM. Draft Recommendation. Materials and Structures, 27 (7), 1994, p. 415-436.

5. BARBUCCI, A.; DELUCCHI, M.; CERISOLA, G. Organic coatings for concrete protection: liquid water and water vapour permeabilities. Progress in Organic Coatings, 30 (4), 1997, p. 293-297.

6. BARBUCCI, A.; DELUCCHI, M.; CERISOLA, G. Crack-bridging ability of organic coatings for concrete: influence of the method of concrete cracking, thickness and nature of the coating. Progress in Organic Coatings, 49 (4), 2004, p. 336-341.

7. LUMA, Ch. Protect concrete from corrosion coatings must be part of a complete strategy. Chemical Engineering, 105 (12), 1998, p. 4.

8. BAMFORTH, P. Options for reducing the risk of reinforced concrete structures and their incorporation into the design process. Anti-Corrosion Methods and Materials, 46 (4), 1999, p. 268-275.

9. VASSIE, P. R.; CALDER, A. Reducing chloride ingress to concrete bridges by impregnants. In Controling Concrete Degradation. Proc of the international seminar, Dundee, Scotland, UK, 1999, p. 133-154.

10. CZARNECKI, L.; LUKOWSKI, P. An usability approach to technical evaluation of the polymer coatings for concrete substrate. In Adhesion Between the Polymers and Concrete. RILEM publications, 1999, p. 173-180.

11. VIPULANANDAN, C.; LIU, J. Glass-fiber mat reinforced epoxy coating for concrete in sulfuric acid environment. Cement and Concrete Research, 32 (2), 2002, p. 205-210.

12. VIPULANANDAN, C.; LIU, J. Film model for coated cement concrete. Cement and Concrete Research, 32 (12), 2002, p. 1931-1936.

13. OGAWA, S.; YOSHIOKA, T.; SUGYIAMA, T. Prediction of chloride penetration and life-cycle cost of concrete bridges. In Concrete Structures in the $21^{\text {st }}$ Century. Proc of the first FIB congress, Osaka, Japan, 2002, p. 8 [CDROM].

14. BEILIN, D.; FIGOVSKY, O. Stress-strain state of polymer chemical-resistant coatings during curing and under operating conditions. Composite Structures, 31 (4), 1995, p. 253-256.

15. SOLOMATOV, V. I.; SELIAJEV, V. P. Chemical resistance of composite building materials. Moscow: Strojizdat, 1987. 261 p. (in Russian).

16. ELIAS, H.-G. An introduction to polymer science. New York, 1997. $470 \mathrm{p}$. 
17. VAYSBURG, A. M.; EMMONS, P. H. How to make today's repairs durable for tomorrow - corrosion protection in concrete repair. Construction and Building Materials, 14 (4), 2000, p. 189-197.
18. MAYS, G. C. Materials for protection and repair of concrete: progress towards European standardization. In Concrete Durability and Repair Technology. Proc of the international conference. Dundee, Scotland, UK, 1999, p. 481-491.

\section{GELŽBETONINIŲ KONSTRUKCIJŲ POLIMERINIŲ APSAUGINIŲ DANGŲ PROJEKTAVIMAS. I DALIS. TEORINE் SAMPRATA}

\section{Z. Kamaitis}

\section{Santrauka}

Agresyviojoje aplinkoje eksploatuojamos gležbetoninès konstrukcijos turi būti apsaugotos nuo irimo. Vienas iš būdų yra polimerinès apsauginès dangos. Polimerai nèra absoliučiai atsparūs ir nelaidūs visoms agresyviosioms aplinkoms. Tačiau degradacijos procesai polimeruose yra gerokai lètesni nei betone. Prognozuoti šiuos procesus labai svarbu, norint teisingai parinkti dangų parametrus bei užtikrinti konstrukcijų, eksploatuojamų agresyviojoje aplinkoje, patikimumą.

Straipsnyje analizuojama polimerinių dangu degradacija. Pateikta degradacijos procesų klasifikacija (1 lentelè) ir jų matematiniai modeliai. Polimerinių dangų vertinimą siūloma formuluoti keturiais ribiniais būviais, naudojant deterministinį ar tikimybinį skaičiavimą ((27), (28) ir (29) formulès). Pateikti ribiniai būviai gali būti naudojami projektuojant gelžbetoninių konstrukcijų apsaugines dangas.

Reikšminiai žodžiai: gelžbetoninès konstrukcijos, korozija, polimerinės dangos, fizinis ir cheminis atsparumas, difuzija, adhezija, projektavimas.

Zenonas KAMAITIS. Dr Habil, Prof Emeritus at the Dept of Bridges and Special Structures. Member of IABSE since 1999. Author and co-author of more than 150 publications, including 6 books. Research interests: concrete structures and bridges, materials, durability, monitoring, and refurbishment. 